\title{
Gambaran Protein Urin pada Primigravida Trimester I dengan Riwayat Orang Tua Hipertensi di Kota Manado
}

\author{
${ }^{1}$ Ni Luh Ayu Sucindrawati \\ ${ }^{2}$ Glady I. Rambert \\ ${ }^{2}$ Siemona Berhimpon
}

\author{
${ }^{1}$ Program Studi Pendidikan Dokter Fakultas Kedokteran Universitas Sam Ratulangi Manado \\ ${ }^{2}$ Bagian Patologi Klinik Fakultas Kedokteran Universitas Sam Ratulangi Manado \\ Email: nlaysucindra@gmail.com
}

\begin{abstract}
Proteinuria is an excessive excretion of protein in urine. It is defined as $300 \mathrm{mg}$ or more potein within 24 hours or $30 \mathrm{mg} / \mathrm{Dl}(+1$ dipstick ) permanently in random urine samples. The main cause of proteinuria in pregnant woman is any desease associated with damage of the urinary tract organs. Furthermore, other causes of proteinuria in pregnant woman are preeclampsia and eclampsia, influenced by parental history of hypertension. This study was aimed to obtain the protein level in first trimester of primigravidas with parental history of hypertension in Manado. This was an observational descriptive study with a cross sectional design. Subjects were taken by using non-probality sampling consecutive sampling type to obtain urine samples from all subjects that matched the criteria and the specified time. The results showed that of 15 urine samples, there were 9 samples of positive protein $(60 \%)$. Conclusion: Protein was found in urine samples of some primigravidas with parental history of hypertension in Manado.
\end{abstract}

Keywords: proteinuria, pre-eclampsia, parental history of hypertension

\begin{abstract}
Abstrak: Proteinuria adalah ekskresi protein berlebihan dalam urin. Proteinuria didefinisikan sebagai terdapatnya $300 \mathrm{mg}$ atau lebih protein dalam $24 \mathrm{jam}$ atau $30 \mathrm{mg} / \mathrm{dL}$ (1+ dipstik) secara menetap pada sampel acak urin. Penyebab utama terjadinya proteinuria pada ibu hamil ialah penyakit yang berhubungan dengan kerusakan pada organ sistem traktus urinarius. Penyebab lain dari munculnya proteinuria pada wanita hamil ialah pre-eklampsia dan eklampsia, dan dipengaruhi oleh faktor riwayat hipertensi pada orang tua. Penelitian ini bertujuan untuk mengetahui kadar protein urin pada primigravida trimester I dengan riwayat orang tua hipertensi di Kota Manado. Jenis penelitian ialah deskriptif observasional dengan desain potong lintang. Subyek penelitian diambil dengan cara non-probability sampling jenis consecutive sampling untuk mendapatkan urin dari semua subyek yang sesuai dengan kriteria dan waktu yang ditentukan. Hasil penelitian memperlihatkan bahwa dari 15 sampel urin, terdapat 9 sampel dengan positif protein $(60 \%)$. Simpulan: Protein urin didapatkan pada sebagian primigravida dengan riwayat orang tua hipertensi di Kota Manado.
\end{abstract}

Kata kunci: proteinuria, pre-eklampsia, riwayat hupertensi pada orang tua

Menurut Federasi Obstetri Ginekologi Internasional, kehamilan didefinisikan sebagai fertilisasi atau penyatuan dari spermatozoa dan ovum dan kemudian dilanjutkan dengan nidasi atau implantasi. Bila dihitung dari saat fertilisasi hingga lahirnya bayi, kehamilan normal akan berlangsung dalam waktu 40 minggu atau 10 bulan atau 9 bulan menurut kelender internasional. Kehamilan terbagi dalam 3 trimester, di mana trimester pertama berlangsung 12 minggu; trimester kedua 15 minggu (minggu ke-13 sampai minggu ke27); dan trimester ketiga 13 minggu 
(minggu ke-28 sampai ke-40). ${ }^{1}$ Kehamilan merupakan proses fisiologis dan alamiah yang melibatkan berbagai perubahan fisik, perubahan sistem respirasi, sistem traktus urinarius, sirkulasi darah, serta perubahan psikologi. ${ }^{1}$

Pada kehamilan dapat dijumpai peningkatan tekanan darah (hipertensi), edema, dan proteinuria yang dapat menjadi faktor penyebab kematian maternal pada wanita hamil. ${ }^{1}$ Menurut World Health Organization (WHO), hipertensi dalam kehamilan masih merupakan salah satu penyebab utama kematian ibu di dunia yaitu berkisar $12 \% .^{2}$ Prevalensi hipertensi dalam kehamilan berkisar 2,6-7,3\% dari seluruh kehamilan. ${ }^{3}$ Angka kejadian preeklampsia di RSUP Prof. Dr. R. D. Kandou Manado tahun 2011 untuk angka kejadian pre-eklampsia ringan 314 kasus $(7,6 \%)$ dan pre-eklampsia berat 103 kasus $(2,5 \%)$ dari 4.147 persalinan. $^{4}$ Data dari Dinas Kesehatan Provinsi Sulawesi Utara menyatakan bahwa pada tahun 2010 terdapat sebanyak 69 kasus kematian ibu dan mengalami peningkatan pada tahun 2011 yaitu menjadi 71 kasus. Pada periode 1 Januari-31 Desember 2014 pasien ibu hamil dengan pre-eklampsia yang di rawat di RSUP Prof. Dr. R. D. Kandou Manado sebanyak 201 dari 3.347 pasien. Prevalensi hipertensi dalam kehamilan di Provinsi Sulawesi Utara ialah $27,1 \%{ }^{4}$

Hipertensi dalam kehamilan merupakan penyebab kematian maternal yang bisa dicegah dengan deteksi dini melalui tes proteinuria. ${ }^{5}$ Proteinuria merupakan komplikasi yang serius dari hipertensi. Adanya proteinuria menunjukkan gangguan fungsi ginjal dan fungsi plasenta yang dapat menimbulkan ancaman pada bayi. Proteinuria didefinisikan sebagai terdapat-nya 300 $\mathrm{mg}$ atau lebih protein dalam 24 jam atau $30 \mathrm{mg} / \mathrm{dL}(1+$ dipstik) secara menetap pada sampel acak urin. ${ }^{6}$ Penyebab utama terjadinya proteinuria pada ibu hamil ialah penyakit yang berhubungan dengan kerusakan pada organ sistem traktus urinarius. Selain itu penyebab lain munculnya proteinuria pada wanita hamil ialah preeklampsia dan eklampsia. $^{7}$
Peningkatan gradual dari tekanan darah, proteinuria, dan edema selama kehamilan merupakan tanda-tanda preeklampsia, terutama pada primigravida. Gejala tersebut akan muncul pada trimester ke III sampai saat melahirkan. Biasanya gejala timbul setelah kehamilan 20 minggu, Jika timbul sebelumnya maka terjadi kehamilan mola hydatidosa (hamil anggur). Primigravida juga merupakan salah satu faktor risiko terjadinya pre-eklampsia dan eklampsia. Penelitian yang dilakukan di RS Kota Denpasar melaporkan insidensi preeklampsia pada primigravida $11,3 \%$ dan angka kematian maternal akibat penyakit ini $8,07 \% .^{8}$

Penelitian ini bertujuan untuk mengetahui gambaran protein urin pada primigravida trimester I dengan riwayat hipertensi pada orang tua di Kota Manado.

\section{METODE PENELITIAN}

Jenis penelitian yang dilakukan ialah deskriptif dengan desain potong lintang. Penelitian ini dilaksanakan di Puskesmas Teling Atas, Tuminting, dan Ranotana. Pemeriksaan sampel urin dilakukan di Laboratorium Pro-kita Manado dengan waktu penelitian pada bulan OktoberDesember 2018.

Populasi penelitian yaitu primigravida trimester I dengan riwayat orang tua hipertensi sebanyak 15 orang. Sampel penelitian ialah urin sewaktu dari 15 primigravida yang memenuhi kriteria inklusi dan bersedia diikutsertakan dalam penelitian. Subyek penelitian diambil dengan cara non-probability sampling jenis consecutive sampling untuk mendapatkan urin dari semua primigravida trimester I dalam waktu dan kriteria yang telah ditentukan.

\section{HASIL PENELITIAN}

Penelitian ini dilakukan terhadap wanita hamil yang datang di puskesmas dan dilanjutkan dengan pemeriksaan laboratorium. Penelitian ini dilakukan pada tiga puskesmas di Manado yaitu Puskesmas Teling Atas, Puskesmas Tuminting dan Puskesmas Ranotana. Pemeriksaan sampel 
urin dilakukan di Laboratorium Prokita.

Pada penelitian ini terdapat sebanyak 15 primigravida trimester I. Tabel 1 memperlihatkan distribusi subyek penelitian berdasarkan usia. Terdapat 2 subyek $(13,33 \%)$ pada kelompok usia $<20$ tahun, 13 subyek $(86,67 \%)$ pada kelompok usia 20-30 tahun; tidak ada subyek $(0 \%)$ pada kelompok usia >35 tahun.

Tabel 1. Distribusi usia primigravida trimester I

\begin{tabular}{ccc}
\hline $\begin{array}{c}\text { Usia } \\
\text { (tahun) }\end{array}$ & Frekuensi & $\begin{array}{c}\text { Persentase } \\
(\boldsymbol{\%})\end{array}$ \\
\hline$<20$ & 2 & 13,33 \\
$20-30$ & 13 & 86,67 \\
$>35$ & 0 & 0 \\
Total & 15 & 100 \\
\hline
\end{tabular}

Tabel 2 menampilkan distribusi subyek berdasarkan usia kehamilan. Terdapat 5 subyek $(33,33 \%)$ dengan usia kehamilan 14 minggu, 7 subyek $(46,67 \%)$ dengan usia kehamilan 4-8 minggu, dan 3 subyek (20\%) dengan usia kehamilan 8-12 minggu.

Tabel 2. Distribusi subyek menurut usia kehamilan

\begin{tabular}{ccc}
\hline $\begin{array}{c}\text { Usia } \\
\text { kehamilan } \\
\text { (minggu) }\end{array}$ & Frekuensi & $\begin{array}{c}\text { Persentase } \\
(\boldsymbol{\%})\end{array}$ \\
\hline $1-4$ & 5 & 33,33 \\
$4-8$ & 7 & 46,67 \\
$8-12$ & 3 & 20 \\
Total & 15 & 100 \\
\hline
\end{tabular}

Tabel 3 menyajikan distribusi subyek penelitian berdasarkan puskemas. Terdapat 3 orang $(20 \%)$ di Puskesmas Teling, 5 orang $(33,33 \%)$ di Puskesmas Tuminting, dan 7 orang $(46,67 \%)$ di Puskesmas Ranotana.

Tabel 3. Distribusi subyek berdasarkan puskemas

\begin{tabular}{ccc}
\hline Puskesmas & Frekuensi & $\begin{array}{c}\text { Persentase } \\
(\mathbf{\%})\end{array}$ \\
\hline Teling Atas & 3 & 20 \\
Tuminting & 5 & 33,33 \\
Ranotana & 7 & 46,67 \\
Total & 15 & 100 \\
\hline
\end{tabular}

Tabel 4 memperlihatkan distribusi berdasarkan tekanan darah subyek penelitian. Terdapat 4 subyek $(26,67 \%)$ dengan tekanan darah 110/80 mm $\mathrm{Hg}, 10$ subyek $(66,67 \%)$ dengan tekanan darah $120 / 80 \mathrm{~mm} \mathrm{Hg}$, dan 1 subyek $(6,66 \%)$ dengan tekanan darah 130/90 mm Hg.

Tabel 4. Distribusi subyek berdasarkan tekanan darah

\begin{tabular}{ccc}
\hline $\begin{array}{c}\text { Tekanan darah } \\
(\mathbf{m m ~ H g})\end{array}$ & Frekuensi & $\begin{array}{c}\text { Persentase } \\
(\boldsymbol{\%})\end{array}$ \\
\hline $110 / 80$ & 4 & 26,67 \\
$120 / 80$ & 10 & 66,67 \\
$130 / 90$ & 1 & 6,66 \\
Total & 15 & 100 \\
\hline
\end{tabular}

Tabel 5 menampilkan distribusi subyek penelitian berdasarkan kadar protein urin. Terdapat 6 subyek (40\%) dengan hasil normal/negatif, 8 subyek $(53,33 \%)$ dengan hasil positif (+), dan 1 subyek $(6,67 \%)$ dengan hasil positif $(++)$.

Tabel 5. Distribusi subyek berdasarkan kadar protein urin

\begin{tabular}{ccc}
\hline $\begin{array}{c}\text { Kadar } \\
\text { protein urin }\end{array}$ & Frekuensi & $\begin{array}{c}\text { Persentase } \\
(\boldsymbol{\%})\end{array}$ \\
\hline Normal/negatif & 6 & 40 \\
Positif (+) & 8 & 53,33 \\
Positif $(++)$ & 1 & 6,67 \\
Total & 15 & 100 \\
\hline
\end{tabular}

\section{BAHASAN}

Berdasarkan hasil penelitian di tiga puskesmas, yaitu Puskesmas Teling, Puskesmas Tuminting, dan Puskesmas Ranotana di Kota Manado yang dilaksanakan pada bulan Oktober 2018 Desember 2018 terdapat 15 primigravida trimester I dengan riwayat orang tua hipertensi yang memenuhi kriteria inklusi.

Kelompok usia primigravida dengan riwayat orang tua hipertensi dan protein positif terbanyak pada kelompok usia 20-30 tahun yaitu 13 orang $(8,67 \%)$, dan paling sedikit pada kelompok usia $<20$ tahun yaitu 2 orang $(13,33 \%)$; tidak ada pada usia $>35$ tahun (Tabel 1). Hasil penelitian ini tidak sesuai dengan teori Cuningham 2013, yang 
menyatakan bahwa usia yang berisiko terkena hipertensi pada kehamilan ialah usia $<20$ tahun atau $>35$ tahun. Kehamilan dengan usia muda maupun tua merupakan suatu keadaan yang dapat menimbulkan risiko komplikasi dan kematian pada ibu. Usia 20-35 tahun ialah periode yang aman untuk melahirkan dengan risiko kematian ibu paling rendah. Pada usia $<20$ tahun ukuran uterus belum mencapai ukuran yang normal untuk kehamilan, akibatnya ibu hamil pada usia tersebut berisiko mengalami penyakit pada kehamilan, sedangkan pada usia 35 tahun kesehatan ibu mulai menurun sehingga ibu hamil pada usia tersebut mempunyai kemungkinan lebih besar untuk mempunyai anak cacat, persalinan lama, dan perdarahan. ${ }^{9}$

Pada pemeriksaan protein urin yang dilakukan pada 15 orang primigravida trimester I dengan riwayat orang tua hipertensi diperoleh hasil usia kehamilan 48 minggu $(46,67 \%)$ lebih banyak dibandingkan 8-12 minggu (20\%) dengan hasil protein positif (Tabel 2). Frekuensi wanita hamil paling banyak pada usia kehamilan 4-8 minggu. Diasumsikan bahwa wanita hamil melakukan pemeriksaan pada usia kehamilan ini karena kecurigaan hamil terjadi saat seorang wanita tidak mengalami menstruasi.

Pada penelitian ini jumlah subyek pada Puskesmas Ranotana lebih banyak dibandingkan kedua puskesmas lainnya (Tabel 3). Sesuai data yang diperoleh, kunjungan ibu hamil di Puskesmas Ranotana lebih banyak dibandingkan Puskesmas Teling dan Tuminting.

Hasil penelitian mendapatkan dari 9 ibu hamil yang protein positif, ditemukan 1 ibu hamil dengan tekanan darah 130/90 $\mathrm{mm} \mathrm{Hg}$ dengan hasil protein urin positif $(++)$, sehingga kemungkinan ibu untuk terkena pre-eklamsia meningkat. Peningkatan tekanan darah selama kehamilan harus diwaspadai karena keadaan ini bisa membahayakan ibu hamil. Beberapa kasus pre-eklamsia dengan komplikasi merupakan penyebab utama kematian pada ibu hamil. Tekanan darah tinggi dapat menurunkan aliran darah ke plasenta yang akan memengaruhi pasokan oksigen dan nutrisi dari janin. Hal ini dapat memperlambat pertumbuhan janin dan meningkatkan risiko saat melahirkan. Tekanan darah dan proteinuria yang semakin meningkat dapat mengancam keselamatan ibu dan janin. ${ }^{10}$

Pada penelitian ini didapatkan protein urin positif pada 9 primigravida trimester I dengan riwayat orang tua hipertensi sedangkan hasil normal/negatif pada 6 oang (40\%). Sampel positif pada ibu hamil trimester I bervariasi, yaitu 8 sampel $(53,33 \%)$ positif (+) dan 1 sampel $(6,67 \%)$ positif (++) (Tabel 5).

Diagnosis hipertensi ditegakkan jika ibu hamil menderita hipertensi sebelum kehamilan, terdapat hipertensi yang resisten, dan munculnya proteinuria. Proteinuria dalam kehamilan juga dapat disebabkan karena dilatasi saluran kemih, yang sering terjadi selama kehamilan terutama pada trimester akhir. Proteinuria yang positif dengan urin dipstik perlu dikonfirmasi dengan pemeiksaan lanjutan untuk memastikan apakah hasilnya benar menunjukkan proteinuria atau tidak.

Berdasarkan hasil penelitian terdapat hubungan antara faktor keturunan dengan kejadian hipertensi dalam kehamilan dan teori yang menyatakan bahwa wanita yang berisiko terkena hipertensi dalam kehamilan antara lain yang memiliki riwayat hipertensi dalam keluarga atau keluarga yang pernah mengalami hipertensi dalam kehamilan. Faktor keturunan adalah faktor yang telah ada dalam diri manusia dan dibawa sejak lahir misalnya diabetes melitus, asma, retardasi mental, dan hipertensi. Telah terbukti bahwa pada ibu yang mengalami pre-eklamsia, $26 \%$ dari anak perempuannya akan mengalami preeklamsia. Jika ada riwayat pre-eklampsia/ eklampsia pada ibu/nenek maka faktor risiko meningkat sampai $\pm 25 \%$. ${ }^{11}$

\section{SIMPULAN}

Berdasarkan hasil penelitian ini dapat disimpulkan bahwa protein urin didapatkan pada sebagian primigravida dengan riwayat orang tua hipertensi di Kota Manado 


\section{SARAN}

Disarankan untuk meningkatkan jumlah sampel dan waktu penelitian agar menghindari terjadinya bias dan sebaiknya diikutsertakan primigravida trimester II dan III.

Pada ibu hamil dengan proteinuria disarankan untuk melalukan pemeriksaan antenatal care (ANC) lebih teratur agar mengoptimalkan kesehatan mental dan fisik dari ibu hamil.

\section{DAFTAR PUSTAKA}

1. Sarwono P. Ilmu Kebidanan (4th ed). Jakarta: Bina Pustaka Prawirohardjo, 2016

2. Maternal mortality: World Health Organization (WHO), 2014.

3. Pratiwi DA. Angka kematian ibu di Indonesia masih jauh dari target MDGs 2015. Kompasiana, 2014.

4. Andini R, Sondakh J, Laihad BJ.Gambaran angka kematian ibu di RSUP Prof. Dr. R. D. Kandou Manado periode Januari 2014-September 2015. eCl. 2016;4(1): $1-7$.
5. Hanretty KP. Ilustrasi Obstetri. Jakarta: Nuha Medika, 2014.

6. Suryono S. Diabetes melitus di Indonesia. Buku Ajar Ilmu Penyakit Dalam (4th ed). Jakarta: FKUI, 2006.

7. Manuaba IGB. Pengantar Kuliah Obstetri, Jakarta: EGC, 2007.

8. Bouatra S, Aziat F, Mandal R, Guo AC, Wilson MR, Knox C, et al. The Human Urine Metabolome. PLoS ONE. 2013;8(9).

9. Cunningham FG, Levenno KJ, Bloom SL, Hauth JC, Rouse DJ, Spong CY. Hipertensi dalam kehamilan. In: Pendit BU, Setia R, editors. Obstetri Williams (23th ed). Jakarta: EGC, 2013; p.740-4.

10. Dharma R, Wibowo N, Raranta HPT. Disfungsi endotel pada pre-eklampsia. Jakarta: Departemen Patologi Klinik FKUI dan Departemen Obstetrik dan Ginekologi FKUI, 2015.

11. Angsar MD. Hipertensi dalam kehamilan. In: Ilmu Kebidanan Sarwono Prawirohardjo (4th ed). Jakarta: Bina Pustaka Sarwono Prawirohardjo, 2010. 